\title{
METODE BREAST CARE MENINGKATKAN VOLUME ASI PADA IBU NIFAS
}

\author{
Yuniarti $^{1^{*}}$ \\ ${ }^{1} J u r u s a n$ Kebidanan Politeknik Kesehatan Kemenkes Palangka Raya \\ Email: yuniartiamit@yahoo.com
}

\begin{abstract}
Abstrak
Cakupan pemberian Air Susu Ibu (ASI) Ekslusif pada bayi di Provinsi Kalimantan Tengah pada tahun 2015 mencapai $27.58 \%$ lebih rendah dibandingkan target nasional pemberian ASI yaitu $80 \%$. Salah satu yang menjadi penyebab ASI eksklusif tidak diberikan adalah rendahnya produksi ASI. Ada beberapa hal yang menghambat terjadinya pengeluaran ASI pada ibu nifas diantaranya rendahnya pengetahuan ibu dalam melakukan breast care, kurangnya pelayanan konseling tentang cara perawatan payudara dari petugas kesehatan, serta kurangnya keinginan ibu untuk melakukan breast care. Tujuan penelitian untuk mengetahui pengaruh breast care terhadap pengeluaran volume ASI pada ibu nifas di Praktik Mandiri Bidan (PMB) di Kota Palangka Raya.Jenis Penelitian ini adalah pre experimental (praeksperimen) dengan model rancangan one group pre-test post-test. Teknik Pengambilan sampel yang digunakan purposive sampling sebanyak 31 ibu nifas didapatkan dari rumus sampling Hypothesis sampling formula test for a population mean by Lemeshow. Pada Ibu nifas diukur jumlah volume ASI pada hari ke 7 pasca persalinan sebelum dilakukan breast care dan pada hari ke 14 setelah dilakukan breast care selanjutnya dilakukan analisis data dengan menggunakan paired $t$-test. Hasil yang didapatkan sebelum dilakukan intervensi rata-rata volume ASI ibu nifas sebesar $0,18 \mathrm{ml}$ sedangkan setelah intervensi didapatkan rata-rata volume ASI ibu nifas sebesar $14,36 \mathrm{ml}$, berdasarkan analisis data terdapat efektivitas Breast care terhadap pengeluaran volume $A S I$ dengan nilai $P=0.000(P<0.05)$. Kesimpulan ada pengaruh yang signifikan terhadap pengeluaran volume ASI pada ibu nifas yang diberikan breast care.
\end{abstract}

Kata kunci: Breast care, Ibu nifas, Volume Air Susu Ibu

\begin{abstract}
The coverage of exclusive breastfeeding in infants in Central Kalimantan Province by 2015 was $27.58 \%$ lower than the national target of breastfeeding at $80 \%$. One of the causes of exclusive breastfeeding is low milk production. There are some things that inhibit the occurrence of breastfeeding volume exposure in non-current mothers, including low knowledge of mothers in breast care, lack of counseling services on how breast care from health workers and lack of mother's desire to do breast care. Research Objectives this study aims to determine the effect of breast care on the expenditure of breast milk volume on postpartum mothers in IPM Palangka Raya. This type of research is pre-experimental with a one group pre-test post-test design model. The sampling technique used was purposive sampling with 31 postpartum mothers obtained from the Hypothesis sampling formula test for a population mean by Lemeshow. The evaluation is done in the day 7 (pretest), the day 14 (posttest) by using measure cup to calculated breastmilk production then analysis using paired $t$-test. Result of research Based on paired t-test there is effectivity of Breast care to the expenditure of breast milk volume with value $P=0.000(P<0.05)$. Conclusion There is a significant relationship to the expenditure of breast care volume on postpartum mothers.
\end{abstract}




\section{Keywords: Breast Care, Post Partum, Breast Milk Volume}

\section{PENDAHULUAN}

Pengetahuan, kesadaran, kemampuan ibu untuk memberikan hak asasi manusia dan hakhak bayi yang sedang menikmati susunya sangat memprihatinkan di Indonesia. Padahal ibu yang telah ditentukan untuk menyusui bayinya yang telah lahir. Secara alami itu adalah proses alami dan juga merupakan tugas mulia bagi ibu sendiri untuk keselamatan pada bayi nanti (Charlick, McKellar, Fielder, \& Pincombe, 2015).

Menurut UNICEF / WHO pada 2011 di World Breastfeeding Week (2012) total 136,7 jutabayilahir di seluruh dunia dan hanya $32,6 \%$ dari mereka yang disusui secara eksklusif pada usia 0 hingga 6 bulan. Ini menggambarkan cakupan pemberian ASI eksklusif di bawah $80 \%$ (Lake, 2012). Di Indonesia ada beberapa hal yang menghambat pemberian ASI eksklusif yaitu kurangnya pengetahuan ibu tentang Breast care dan kurangnya penggunaan Breast care pada perawatan ibu nifas (Wulandari, 2018).

Kementrian Kesehatan melalui Program Peningkatan Gizi Masyarakat telah menargetkan cakupan pemberian ASI eksklusif sebesar $80 \%$, rekomendasi pemberian ASI eksklusif hingga usia 6 bulan tampaknya masih terlalu sulit untuk dilaksanakan. Data dari Survei Demografi dan Kesehatan Indonesia 1997-2007 menunjukkan penurunan prevalensi ASI eksklusif dari 40,2\% pada tahun 1997 menjadi 39,5\% dan 32\% pada tahun 2003 dan 2007. Cakupan pemberian ASI eksklusif pada bayi rata-rata di Provinsi Kalimantan Tengah pada tahun 2015 hanya mencapai 27,58\% (Dinkes Provinsi Kalimantan Tengah, 2015).

Dampak dari tidak melakukan perawatan payudara atau breast care dapat mengakibatkan beberapa dampak negatif yang puttingnya tidak menonjol, anak yang sulit menyusui, ASI lebih lama keluar, volume susu terbatas, payudara kotor, ibu tidak siap untuk menyusui, terutama kulit putting payudara akan mudah tergores. (Nilamsari, 2014). Sehingga penelitian ini dilakukan untuk mengetahui efektifitas breast care terhadap peningkatan volume ASI pada ibu nifas.

\section{METODE PENELITIAN}

Menggunakan pre-eksperimental one group pretest-posttest design, penelitian ini dilakukan pada bulan Januari hingga April 2018 di Praktek Bidan Mandiri (PMB) Kota Palangkaraya. Populasi dalam penelitian ini adalah ibu nifas normal hari 7 sampai hari ke 14 . Penelitian ini menggunakan Teknik pengambilan sampel purposive sampling. Sebanyak 31 ibu nifas didapatkan dari rumus sampling Hypothesis sampling formula test for a population mean by Lemeshow. Ibu nifas dipilih yang sesuai kriteria inklusi dan tersedia pada lokasi penelitian saat sedang dilakukan penelitian, diberikan intervensi berupa breast care 1 kali sehari selama 7 hari pada waktu yang sama. Pengumpulan data menggunakan cara wawancara, informed consent dan pengukuran Volume ASI menggunakan gelas ukur pada ibu nifas hari ke 7 sebelum breast care dan hari ke 14 nifas setelah breast care yang bersalin di Praktek Mandiri Bidan Kota Palangkaraya, Sebelum data dianalisa dilakukan uji normalitas data menggunakan Uji Shapiro wilk karena besar sampel $<50$ menghasilkan data berdistribusi normal. Selanjutnya analisis data menggunakan uji paired t-test untuk mengetahui efektivitas Breast care terhadap peningkatan volume ASI pada ibu nifas. 


\section{HASIL PENELITIAN}

Penelitian yang dilakukan menberikan hasil sebagai berikut:

Tabel 1. Distribusi Frekuensi Responden Berdasarkan Usia Ibu Nifas

\begin{tabular}{ccc}
\hline Usia & Frekuensi & $\%$ \\
\hline$\leq 35$ tahun & 21 & $67,7 \%$ \\
$>35$ tahun & 10 & $32,3 \%$ \\
\hline
\end{tabular}

Tabel 1 di atas menunjukkan data diperoleh dari sampel 31 responden bahwa kelompok umur paling banyak yaitu usia $\leq 35$ tahun sebanyak 21 responden $(67,7 \%)$

Tabel 2 Distribusi Frekuensi Responden Berdasarkan Pekerjaan Ibu Nifas

\begin{tabular}{ccc}
\hline Variabel & Frekuensi & $\%$ \\
\hline Ibu Rumah & 14 & 45,2 \\
Tangga (IRT) & & \\
Kerja & 17 & 54,8 \\
\hline
\end{tabular}

Tabel 2 menunjukkan dari 31 responden bahwa yang paling banyak ibu yang bekerja sebanyak 17 responden (54,8\%).

Tabel 3 Perbedaan Volume ASI Sebelum dan Sesudah Breastcare pada Ibu Nifas

\begin{tabular}{|c|c|c|c|c|}
\hline $\begin{array}{l}\text { Perawatan } \\
\text { Payudara }\end{array}$ & $\begin{array}{l}\text { Rata- } \\
\text { rata } \\
\pm \text { SB } \\
\text { (ml) }\end{array}$ & $\begin{array}{l}\text { Perbedaan } \\
\text { rerata } \pm \text { SB } \\
\quad(\mathrm{ml})\end{array}$ & $\begin{array}{c}\mathrm{Cl} \\
95 \%\end{array}$ & $P$ \\
\hline $\begin{array}{c}\text { Sebelum } \\
\text { intervensi } \\
\text { (Hari 7) }\end{array}$ & $\begin{array}{c}0,18 \\
\pm \\
0,12\end{array}$ & $14,18 \pm 1,79$ & $\begin{array}{c}13,53 \\
- \\
14,84\end{array}$ & 0000 \\
\hline $\begin{array}{c}\text { Setelah intervensi } \\
(\text { Hari 14) }\end{array}$ & $\begin{array}{c}14,36 \\
\pm \\
1,84\end{array}$ & & & \\
\hline
\end{tabular}

Tabel 3 Sebelum dilakukan intervensi rata-rata volume $A S I$ ibu nifas sebesar $0,18 \mathrm{ml}$ sedangkan setelah intervensi didapatkan ratarata volume ASI ibu nifas sebesar $14,36 \mathrm{ml}$. Terdapat perbedaan rata-rata volume ASI ibu nifas antara sebelum dan sesudah intervensi yaitu peningkatan volume ASI sebesar $14,18 \mathrm{ml}$. Uji statistic Paired $t$-test didapatkan nilai $\mathrm{p}$ value 0000 artinya ada perbedaan yang signifikan.

\section{PEMBAHASAN}

Karakteristik ibu nifas pada penelitian ini terbanyak memiliki usia $\leq 35$ tahun, usia ibu mempengaruhi kesehatan ibu karena berhubungan dengan kondisi kehamilan, kelahiran, dan kelahiran, dan pengasuhan juga menyusui bayinya, ibu usia 20-35 tahun disebut sebagai periode reproduksi sehat, di mana usia tersebut diharapkan mampu menyelesaikan masalah yang dihadapi dengan tenang secara emosional, terutama dalam menghadapi kehamilan, persalinan, pascapersalinan, dan perawatan bayinya. Pada usia primipara 35 tahun keatas di mana produksi hormone berkurang, berakibat pada menurunnya proses laktasi.(Utami, 2008)

Karakteristik ibu nifas pada penelitian ini berdasarkan pekerjaan sebagian besar responden yang melakukan Breastcare sebanyak 17 responden $(54,8 \%)$ bekerja dengan terbukanya peluang kerja dan tuntutan untuk bekerja untuk mendukung keluarga mereka maka kebanyakan ibu memilih bekerja di luar rumah, ibu yang bekerja tidak dapat berhubungan sepenuhnya dengan bayi, menyebabkan frekuensi pemberian ASI menurun dan produksi ASI akan menurun. Keadaan ini menyebabkan ibu berhenti menyusui. Dengan demikian, seorang ibu yang bekerja untuk menyusui secara eksklusif kemungkinan menurun dalam kuantitas dan kualitas.(Henderson \& Redshaw, 2011)

Berdasarkan hasil penelitian sebelumnya untuk menilai efektivitas breast care pada ibu nifas terhadap berat bayi lahir dan hormone prolactin menggunakan quasi eksperimental dengan rancangan nonequivalent time sampel design yang mendukung hasil penelitian ini 
bahwa terdapat perbedaan yang bermakna pada berat badan bayi dan hormone prolactin dengan peningkatan $72,1 \%$, sebelum dan sesudah Breast care pada ibu nifas (Mutika, Suwondo, \& Tangwun, 2018). Breast care dilakukan dengan benar dan teratur merangsang pelepasan ASI dan mengurangi risiko cedera saat menyusui. Teknik menyusui yang salah akan memengaruhi bentuk payudara. Breast care secara fisiologis akan merangsang payudara untuk mensekresikan hormone prolactin lebih banyak dan hormone oksitosin untuk merangsang kelenjar susu melalui pemijatan. Secara fisiologis sejak hari ketiga hingga hari keenam setelah melahirkan, menyusui biasanya diproduksi, payudara menjadi sangat penuh. (Wulandari, 2018). Sejalan dengan hasil penelitian ini bahwa terdapat peningkatan volume ASI setelah ibu nifas mendapatkan breast care.

\section{SIMPULAN DAN SARAN}

1. Simpulan

Berdasarkan hasil penelitian bahwa intervensi breast care mampu memberikan efek peningkatan volume ASI pada ibu nifas.

2. Saran

Breastcare dapat dijadikan rekomendasi sebagai tambahan perawatan rutin bagi ibu nifas untuk membantu keberhasilan ASI Ekslusif.

\section{DAFTAR PUSTAKA}

Charlick, S., McKellar, L., Fielder, A., \& Pincombe, J. (2015). interpretative phenomenological Analysis: Implementing research to Influence Breastfeeding Education. International Journal of Childbirth Education, 30(2), 49-54.

Dinkes Provinsi Kalimantan Tengah. (2015). Profil kesehatan 2015 provinsi kalimantan tengah 2015, (09), 124.

Henderson, J., \& Redshaw, M. (2011). Midwifery factors associated with successful breastfeeding. Child: Care, Health and Development, 37(5), 744-753. https://doi.org/10.1111/j.1365-

\subsubsection{7.x}

Lake, A. (2012). Healthy Baby, Healthy Planet. Unicef. Retrieved from www.unicef.org

Mutika, W. T., Suwondo, A., \& Tangwun, R. (2018). bayi dan hormon prolaktin: studi awal. Berita Kedokteran Masyarakat, 34(4), 175-178.

Nilamsari, M. A. (2014). Pengaruh Perawatan Payudara Terhadap Kelancaran Eksresi ASI Pada lbu Post Partum Di Rumah Bersalin Mardi Rahayu SEmarang. Jurnal IImu Keperawatan Dan Kebidanan, I/(2), 1-8.

Utami, R. (2008). Inisiasi Menyusu Dini Plus Asi Ekslusif. (Y. Harlinawati, Ed.) (II). Jakarta: Pustaka Bunda.

Wulandari, C. (2018). Hubungan Perawatan Payudara Pada Ibu Postpartum Dengan Kelancaran Pengeluaran ASI Di Desa Galak Kecamatan Slahung Kabupaten Ponorogo. Jurnal Delima Harapan, 9(8), 48-54. 